\title{
Utilization of Fruit Waste for the Production of Citric Acid by using Aspergillus Niger
}

\author{
Satheeshkumar Subramaniyan', Sivagurunathan Paramasivam², Muthulakshmi Kannaiyan², Uma \\ Chinnaiyan*
}

Department of Microbiology, Faculty of Science, Annamalai University, Annamalai nagar, Chidambaram-608002, India

\begin{abstract}
The main organic acids in industrial used were citric, acetic, tartaric, malic, lactic and gluconic acid. The most utilized organic acid is citric acid or tricarboxylic acid. Chemical synthesis of citric acid is more costly than fermentation. The citrus processing industry generates tons of waste such as peel and segment membranes resulting from the extraction of citrus juice in industrial plants. About 6 isolates were obtained from the fruit waste dumped soil and they were subjected to screening for citric acid production. A. niger over other potential citric acid-producing organism towards efficient utilization of agroindustry residues and by-products for citric acid production. It was grown on PDA plates at a temperature of $28^{\circ} \mathrm{C}$ for 5 to 7 days. Fruit wastes like orange peel, sweet lime peel, banana peel and pineapple peel as a potential substrate for the production of citric acid using A. niger isolates. The nitrogen source of the fermentation medium will have a direct effect on the yield of citric acid. Among the four fruit wastes, citric acid production was maximum from orange peel followed by sweet lime peel, pineapple peel and banana peel respectively. Orange peel contains soluble sugars and pectin as the main components. Study the impact of different carbon sources on citric acid., the basal media were supplemented with glucose, sucrose, fructose, maltose and the fermentation were carried up to 5 days at $30^{\circ} \mathrm{C}$. Nitrogen sources on the fermentation were studied by incorporating ammonium phosphate, potassium hydrogen phosphate and peptone. The effect of lower alcohol incorporation on the fermentation of citric acid was studied.
\end{abstract}

Article Info: Received 09 July 2019; Review Completed 21 Aug 2019; Accepted 25 Aug 2019; Available online 30 Aug 2019

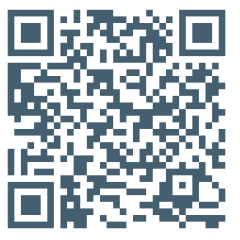

\section{Cite this article as:}

S. Satheeshkumar, P. Sivagurunathan, K. Muthulakshmi, C. Uma, Utilization of Fruit Waste for the Production of Citric Acid by using Aspergillus Niger, Journal of Drug Delivery and Therapeutics. 2019; 9(4-A):9-14

http://dx.doi.org/10.22270/jddt.v9i4-A.3487

*Address for Correspondence:

Uma Chinnaiyan, Department of Microbiology, Faculty of Science, Annamalai University, Annamalai nagar, Chidambaram-608002, India

\section{INTRODUCTION}

The citric acid (2-hydroxy-propane 1, 2, 3-tricarboxylic acid) derives its name from the Latin word citrus, the fruit of the citrus tree which resembles a lemon. Citric acid is a tricarboxylic acid with a molecular weight of $210.14 \mathrm{Da}^{1}$. With an estimated annual production of about 10,00000 tons, citric acid is one of the fermentation products with the most elevated level of production world wide ${ }^{2}$. A considerable amount of citric acid is required in several industrial processes ${ }^{3}$.The food industries consume about $70 \%$ of the total citric acid production, while other industries (Pharmaceuticals, Beverages, etc) consume the remaining $30 \% 4$. Chemical synthesis of citric acid is more costly than fermentation. Various kinds of yeast, fungi and some bacteria are known to produce citric acid5.The reason for choosing $A$. niger over other potential citric acidproducing organism are cheap raw materials used as substrate; high consistent yields. There has been an increasing trend towards efficient utilization of agroindustrial residues and by-products for citric acid production 6 . India positions sixth place in the production of citrus fruits in the world and the citrus fruit wastes are also generated in million tons for every year ${ }^{7}$. The citrus processing industry generates tons of waste such as peel and segment membranes resulting from the extraction of citrus juice in industrial plants. The management of these wastes, which produce odor and soil pollution, represents a noteworthy issue for the food industry8.

Orange peel contains soluble sugars and pectin as the main components. According to to ${ }^{9}$, the orange peel is constituted by soluble sugars, starch, fiber, (cellulose, $9.21 \%$ wt; hemicelluloses, $10.5 \% \mathrm{wt}$; lignin, $0.84 \%$ wt and pectins, $42.5 \% \mathrm{wt}$ ) ashes, $3.50 \% \mathrm{wt}$; fats, $1.95 \% \mathrm{wt}$; and proteins, $6.50 \% w^{10}$. Peels of sweet lime contain a higher concentration of phenolics, flavonoids, ascorbic acids, carotenoids and reducing sugars ${ }^{11}$. Pineapple peel is a byproduct resulting from the processing of pineapple into slices and represents about $10 \%(\mathrm{w} / \mathrm{w})$ of the weight of the original fruit. Pineapple peel is rich in cellulose, hemicellulose and other carbohydrates ${ }^{12}$. 
Banana is one of the most important major fruit crops grown in India. In respect of area and production, it ranks second only to mango. The banana culture in India is as old as Indian civilization. The peel of banana was a rich source of water, sugar, protein, fat, fiber, tannin, carotene, pigments ${ }^{13}$. Due to the impact of dumping fruit wastes into the environment and about the wide applications of citric acid, we carried out studies to test the potential of fruit wastes like orange peel, sweet lime peel, banana peel and pineapple peel as a substrate to produce citric acid.

\section{MATERIALS AND METHODS}

\section{Isolation of fungi}

\section{Determination of fungal load from fruit waste dumped soil}

Fungal isolates were obtained from the fruit waste dumped soil. The soil samples were collected in sterile polythene bags and brought to the laboratory for further analysis. The soil sample was serially diluted, spread plate method was performed using the dilutions $10^{-3}, 10^{-4}$ and $10^{-5}$ in RBA medium and incubated at $30^{\circ} \mathrm{C}$ for 5 days. After incubation, the black color colonies were suspected as Aspergillus $s p$ and selected for the screening of citric acid production.

\section{Screening of fungal isolates for citric acid production}

The fungal isolates were subjected to primary screening for the production of citric acid as per the method described by ${ }^{12}$. Czapek-Dok (CD) agar medium was prepared with bromocresol green indicator and plated on to the sterile Petri plates. After solidification, $0.5 \mathrm{ml}$ of spore suspension of fungal isolates were transferred to each of the Petri plates and incubated at $30^{\circ} \mathrm{C}$ for 5 days. Formation of yellow zones around the colony is the indication of citric acid producers. The isolates that produced the widest yellow zone were selected for further studies.

\section{Identification of fungal isolates}

The citric acid-producing fungal isolates were subcultured on to PDA plates, incubated at room temperature for five days. After incubation, the isolates were identified based on their cultural characteristics and microscopic observation using Lactophenol Cotton Blue (LPCB) staining method.

\section{Preparation of substrate for citric acid production}

\section{Collection and pretreatment of fruit waste samples}

The fruit waste samples viz., orange peel, sweet lime peel, banana peel and pineapple peel were collected from local fruit market and juice shop located around Chidambaram Taluk. The collected fruit waste samples were dried in a hot air oven at $60^{\circ} \mathrm{C}$ for $2 \mathrm{hrs}$. Then the dried samples were cut into $2 \mathrm{~mm}$ sized particles, were used as substrate for citric acid production.

\section{Production of citric acid}

\section{Inoculum preparation}

The strains of $A$. niger were grown on PDA plates at a temperature of $28^{\circ} \mathrm{C}$ for 5 to 7 days. After incubation, the plates were washed with sterile $0.1 \%$ of Tween 80 solution to collect the spores. The number of spores was counted using haemocytometer. The suspension containing $10^{8}$ spores/ml were citric acid is used as an ingredient for production? ${ }^{7}$.

\section{Fermentation}

The basic medium for fermentation was prepared by adding $5 \mathrm{~g} \mathrm{(5 \% )}$ pretreated substrate in $100 \mathrm{ml}$ of distilled water.
Five grams of each substrate were taken in separate flasks and sterilized at $121^{\circ} \mathrm{C}, 15 \mathrm{lbs}$ pressure for $15 \mathrm{~min}$. Autoclaving of the substrate was done to provide proper cooking of the substrate and to kill the microorganisms. After sterilization, the media were inoculated with strains of A. niger $\left(10^{8}\right.$ spores $\left./ \mathrm{ml}\right)$ and incubated at $30^{\circ} \mathrm{C}$ for 5 days. Methanol $3 \%(\mathrm{w} / \mathrm{v})$ was added to the medium before inoculation. After fermentation, the media were diluted with the addition of $100 \mathrm{ml}$ of distilled water and then filtered by using Whatman No.1 filter paper. The resulting filtrate was used for subsequent analysis.

\section{Determination of citric acid}

Citric acid was determined titrimetrically (AOAC, 1995) by using $0.1 \mathrm{~N} \mathrm{NaOH}$ and phenolphthalin as an indicator. The percentage of citric acid was calculated according to the following formula:

Normality $X$ Volume of NaOH X Equiv.Wt. of citric acid

\% Citric acid = - Weight of sample (g) X10

Parameter optima are important in any type of fermentation process, because the production may get an increase or decrease in respect to media components, $\mathrm{pH}$, temperature, media components, etc. To study the effect of above-said parameters, the following experiments were carried out.

\section{i. Effect of medium components on citric acid production}

Study the impact of different carbon sources on citric acid., the basal media were supplemented with glucose, sucrose, fructose, and maltose ( 5 to $15 \%(\mathrm{w} / \mathrm{v}$ )) and the fermentation was carried up to 5 days at $30^{\circ} \mathrm{C}$. The culture filtrate obtained after fermentation was analyzed for citric acid production.

\section{ii. Effect of nitrogen sources}

The effect of different nitrogen sources on the fermentation was studied by incorporating ammonium phosphate, potassium hydrogen phosphate and peptone $(0.5 \%)$. The culture filtrate was taken after fermentation was analyzed for citric acid production.

\section{iii. Effect of lower alcohols}

The effect of lower alcohol incorporation on the fermentation of citric acid was studied. The media were added with methanol and ethanol at a different concentration ranging from 1 to $4 \%$. The resulting culture filtrate after fermentation was used to estimate citric acid production.

\section{iv. Effect of trace elements}

To study the effect of trace elements, the media were introduced with copper, iron and zinc at a concentration of $10 \mathrm{ppm}$. The culture filtrate was analyzed for citric acid production.

\section{v. Effect of $\mathrm{pH}$.}

To study the effect of $\mathrm{pH}$ on the fermentation of citric acid, the media were adjusted with different $\mathrm{pH}$ ranging from 2 to 6. The culture filtrate obtained after fermentation was analyzed for citric acid production.

\section{vi. Effect of temperature}

The influence of temperature on the production of citric acid was determined. The fermentation media were incubated at different temperature levels viz., $20^{\circ} \mathrm{C}, 25^{\circ} \mathrm{C}, 30^{\circ} \mathrm{C}$ and $35^{\circ} \mathrm{C}$. 
After fermentation, the culture filtrate of the media was taken to estimate citric acid production.

\section{EXPERIMENTAL RESULTS}

The fruit wastes such as orange peel, sweet lime peel, banana peel and pineapple peel were collected, dried and cut into $2 \mathrm{~mm}$ sized particles. These particles were used throughout the study.

\section{Determination of fungal load from fruit waste dumped soil}

Serial dilution technique was followed to determine the fungal load of fruit waste dumped soil. The fungal load of the samples was determined as $52 \times 10^{2} \mathrm{CFU} /$ gm; Black colored colonies were selected for the screening of citric acid production.

\section{Screening of fungal isolates for citric acid production}

About 6 isolates were obtained from the fruit waste dumped soil and they were subjected to screening for citric acid production. The isolates were designated as FI - 1 to FI- 6 for convenience. Among the 6 isolates, two isolates (FI-1 and FI3) produced the widest zone and they were selected for further studies (Table.1).
Table-1: Screening of fungal isolates for citric acid production

\begin{tabular}{|c|c|c|}
\hline S. No & Isolates & Citric acid production \\
\hline 1. & FI-1 & ++++ \\
\hline 2. & FI-2 & + \\
\hline 3. & FI-3 & ++++ \\
\hline 4. & FI-4 & - \\
\hline 5. & FI-5 & + \\
\hline 6. & FI-6 & - \\
\hline
\end{tabular}

- Indicates no citric acid production,

+ Least producers of citric acid production,

++++ Best producers of citric acid production.

\section{Citric acid production}

The citric acids produced from different fruit wastes were estimated and the results presented in Figure -1. Among the four fruit wastes used, citric acid production was maximum from orange peel, i.e. $6.0 \%, 9.8 \%$ by A. niger I and A. niger II respectively. Then it was followed by sweet lime peel, pineapple peel and banana peel respectively. A. niger II gave better yields when compared with $A$. niger I. So, further studies were carried out by employing orange peel as a substrate and A. niger II as a fermentative organism.

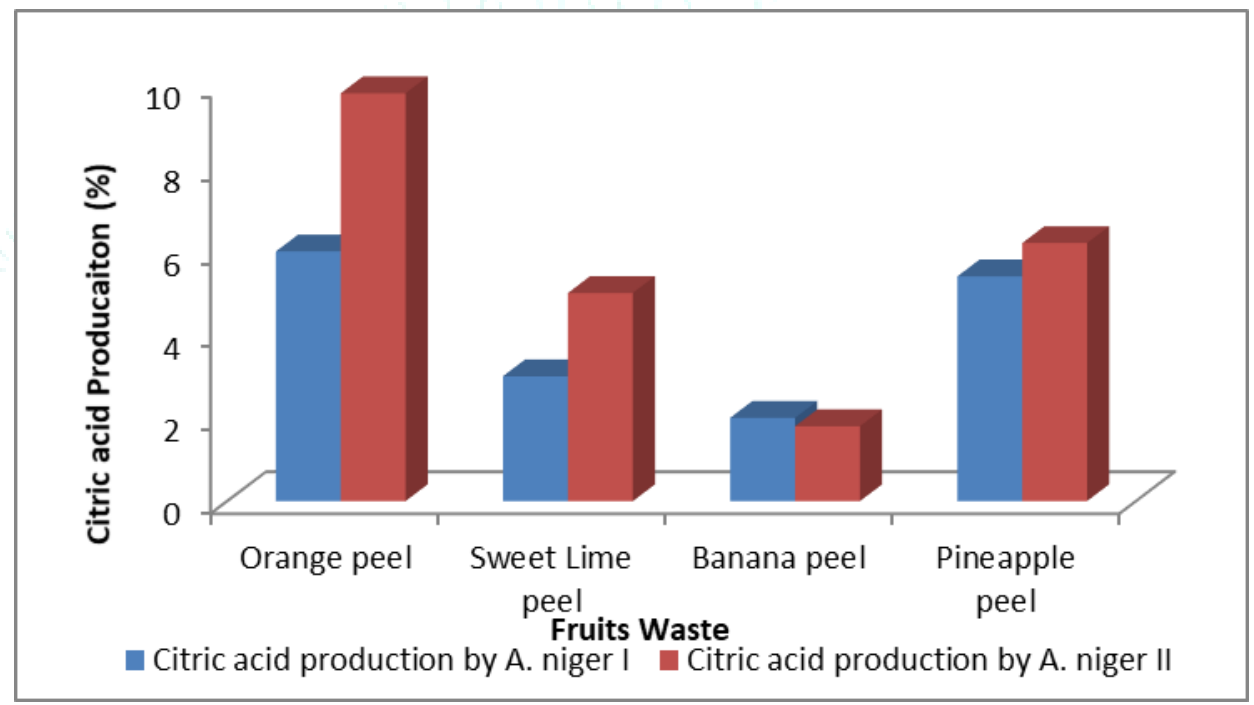

Figure: 1 Citric acid production by $A$. niger strains from different fruit wastes

\section{Optimization of the fermentation process}

Effect of pH, Temperature, Trace Elements, Lower Alcohols

Citric acid production by A. niger II from orange peels with different concentration of glucose, sucrose, fructose and maltose were analyzed. Among the different carbon sources tested, sucrose supplementation showed better yields of citric acid. After 6 days of incubation, the results indicated that maximum production of citric acid (13.6\%) was observed with $10 \%$ sucrose supplemented fermentation media. Sucrose concentrations such as $5 \%$ and $15 \%$ also showed better yield $(9.2 \%, 12.8 \%)$ than the other sugars tested.
Table-2 Effect of lower alcohols on citric acid production

\begin{tabular}{|c|c|c|c|}
\hline \multirow{2}{*}{$\begin{array}{c}\text { S. } \\
\text { No }\end{array}$} & \multirow{2}{*}{$\begin{array}{c}\text { Concentrations } \\
\text { used (\%) }\end{array}$} & \multicolumn{2}{|c|}{$\begin{array}{c}\text { Citric acid production } \\
\text { (\%) }\end{array}$} \\
\cline { 3 - 4 } & & Methanol & Ethanol \\
\hline 1 & 1 & 12.8 & 13.6 \\
\hline 2 & 2 & 13.9 & 12.2 \\
\hline 3 & 3 & 10.4 & 9.0 \\
\hline 4 & 4 & 7.4 & 7.0 \\
\hline
\end{tabular}

Table-3: Effect of trace elements on citric acid production

\begin{tabular}{|c|c|c|}
\hline S. No & $\begin{array}{c}\text { Trace elements } \\
(\mathbf{1 0} \mathbf{~ p p m})\end{array}$ & $\begin{array}{c}\text { Citric acid } \\
\text { production } \mathbf{( \% )}\end{array}$ \\
\hline 1. & $\mathrm{Cu}^{2+}$ & 13.0 \\
\hline 2. & $\mathrm{Fe}^{2+}$ & 9.0 \\
\hline 3. & $\mathrm{Zn}^{2+}$ & 11.8 \\
\hline
\end{tabular}




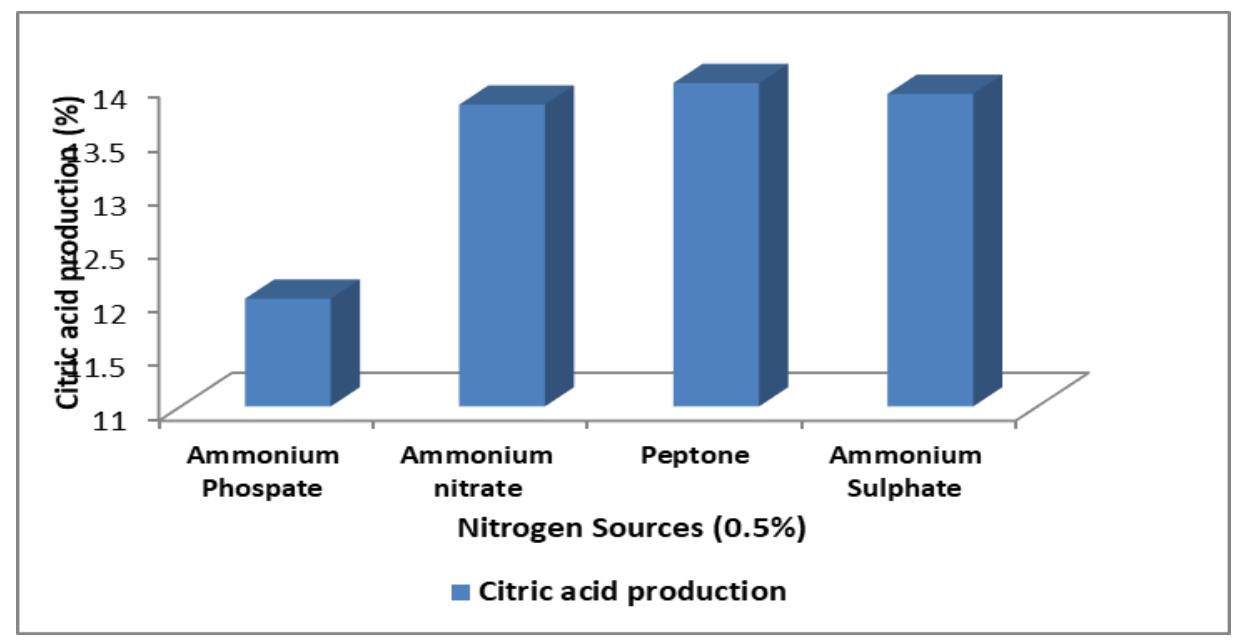

Figure: 2 Effect of nitrogen sources on citric acid production using orange peels as a substrate

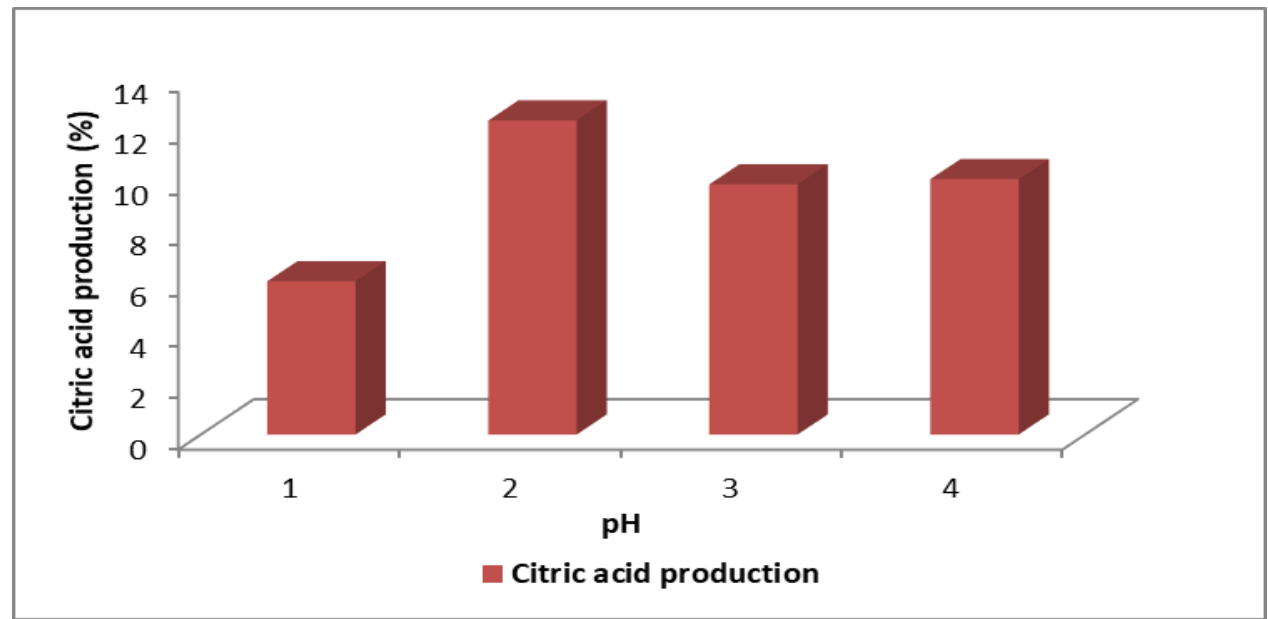

Figure: 3: Effect of pH on citric acid production

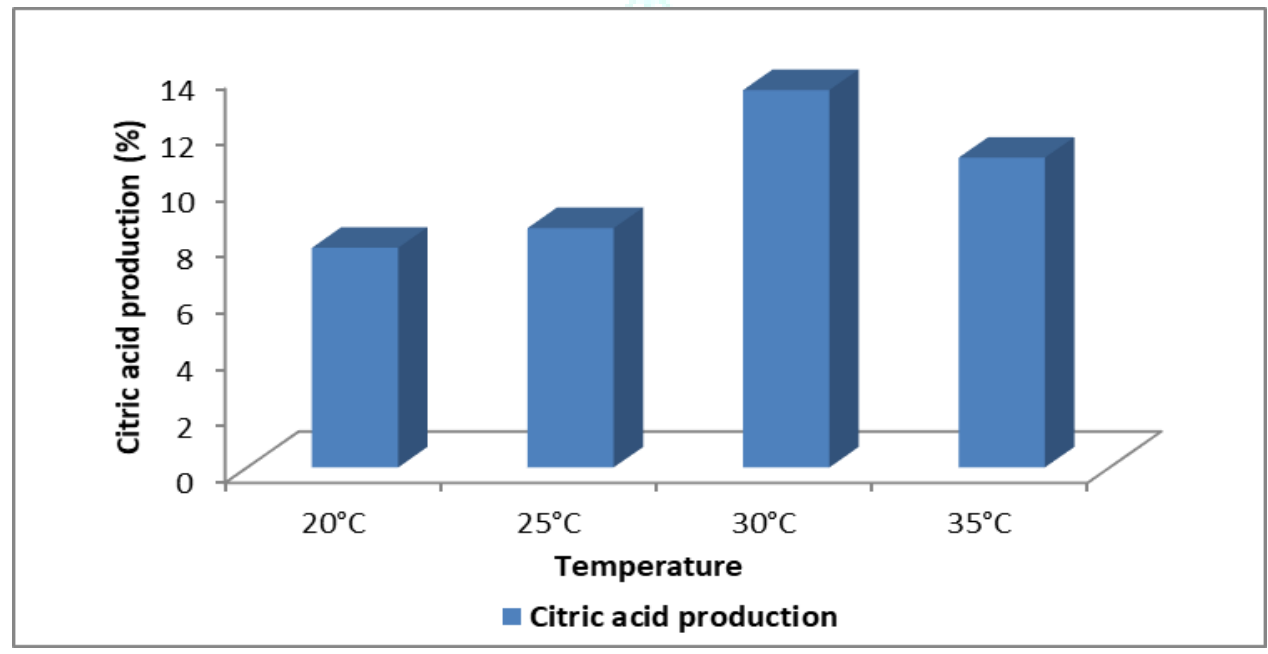

Figure: 4: Effect of temperature on citric acid production

\section{DISCUSSION}

Organic acids have a long history of being utilized as food additives and preservatives for preventing food spoilage and extending the shelf life of food 14 . The main organic acids in industrial use are citric, acetic, tartaric, malic, lactic and gluconic acid. The most utilized organic acid is citric acid 15 , 16 .

The present investigation was mainly focused on the fruit wastes like orange peel, sweet lime peel, banana peel and pineapple peel as a potential substrate for the production of citric acid using A. niger isolates. Among the six isolates obtained from fruit, waste dumped soil, two isolates were better producers of citric acid (A. niger I and II). The best fungal isolates were identified through morphological characteristics by LPCB staining method and colony characteristics on PDA plates. ${ }^{17}$ Isolated A. niger RCNM17 from the soil of rotten fruit dump outside a wholesale fruit stall.18Isolated three fungal isolates, among them only one isolate of $A$. niger produced maximum citric acid from 
different agronomic waste viz., grape, orange, apple, vegetable, tapioca and coconut husk. In our study, the isolate A. niger II produced maximum amount of citric acid (9.8\%) from orange peel. Then it was followed by pineapple peel (6.2\%), sweet lime peel (5.0\%) and banana peel $(1.8 \%)$ respectively. (fig-1). Many authors used different variety of fruit wastes for the production of citric acid. They produced citric acid by utilizing different fruit wastes such as grape pomace, orange peel, kiwifruit peel ${ }^{19,20}$, pineapple wastes, citrus waste and banana peel ${ }^{21,22}$. ${ }^{12}$ Used different varieties of banana peel for producing citric acid by A. niger.

Parameter optima are of considerable importance to increase citric acid yield. The best isolate A. niger II and orange peels alone selected for optimization studies. Citric acid production from orange peel was tested at different $\mathrm{pH}$ levels in order to optimize the $\mathrm{pH}$. $\mathrm{pH}$ did not have any influence within the range of 1.95 to $3.10{ }^{23}$. ${ }^{24}$ Have indicated that a $\mathrm{pH}$ of 2.5 is a clear optimum for final product concentration. Herein, pH 3.0 was found to be optimum for better production of citric acid (12.3\%). Likewise, ${ }^{25}$ recommended that $\mathrm{pH}$ should be kept low, for the better yield of citric acid (Fig.3).

Effect of temperature on the citric acid production by the different organisms was submitted by many authors. ${ }^{26}$ Stated that incubation temperature should be in the range of 28 to $32^{\circ} \mathrm{C}$. In our study, the temperature of $30^{\circ} \mathrm{C}$ was better for citric acid production (13.4\%). If the temperature decreases or increases above $30^{\circ} \mathrm{C}$, the production rate also gets reduced. Similar results were observed with the study conducted by ${ }^{12}$ (Fig.4).

${ }^{27}$ Studied the impact of different types and concentration of sugar on citric acid production. Herein, different carbon sources were tried, among them sucrose $(10 \%)$ yielded the maximum amount of citric acid (13.6\%), followed by glucose, maltose and then fructose. This result is agreed with ${ }^{12}$, they proposed that citric acid yield was maximum from pineapple waste when sucrose $(15 \%)$ used as a carbon source. ${ }^{28}$ Stated that sucrose can be readily attacked by the microbial intracellular enzymes, because of its low molecular weight. ${ }^{29}$ Found that nutrient medium incorporated with sucrose recorded maximum citric acid production than the glucose added medium. They concluded that glucose is not suitable carbon source for higher production of citric acid by A.niger.

The nitrogen source of the fermentation medium will have a direct effect on the yield of citric acid ${ }^{30}$. Effect of different nitrogen sources on citric acid production by A. niger was studied by ${ }^{31}$. They found that the optimal concentration of ammonium sulphate was $5 \mathrm{~kg} \mathrm{~m}^{-3}$. ${ }^{32}$ Reported that citric acid production starts only after the consumption of nitrogen sources. In our investigation, 4 different nitrogen sources were used. Among the four, peptone $(0.5 \%)$ yielded maximum citric acid (14.6\%) followed by ammonium sulphate, ammonium nitrate and ammonium phosphate respectively (Fig-2). Likewise,12 reported that supplementation of the basal medium with ammonium nitrate $(0.25 \%)$ gave increase in citric acid production from pineapple waste. ${ }^{33}$ Stated that ammonium sulphate incorporation increased the yield of citric acid from tapioca and pineapple waste.

The addition of lower alcohols like methanol, ethanol, npropanol and carbohydrate raw materials could increase the yield of citric acid ${ }^{23}$. ${ }^{34}$ Stated that alcohol could be used as a stimulant to enhance the yield of citric acid. According to ${ }^{35}$ the stimulatory effect of methanol may be due to reduction in the inhibitory effects of metal ions. In the present work, effect of methanol and ethanol on citric acid production were compared. Methanol at 2\% concentration gave $13.9 \%$ of citric acid whereas ethanol $1 \%$ recorded $13.6 \%$ of citric acid. (Table-2). These results are comparable with the results obtained by12,36. As per them, lower concentration of methanol has stimulatory impact on citric acid production. ${ }^{37}$ Reported that both methanol and ethanol under optimized conditions increases the productivity of citric acid.

Trace element supplementation in the fermentation media plays a role in affecting the yields of citric acid. The trace elements addition should be optimum unless they will not allow high production. As indicated by Yogitoglu (1992) ${ }^{24}$, the level of manganese, iron, copper and zinc are quite critical. If the levels of these trace elements are other factors have less pronounced effects. In our study, three trace elements viz., $\mathrm{Cu}^{2+}, \mathrm{Fe}^{2+}$ and $\mathrm{Zn}^{2+}$ were incorporated to study their effect on citric acid production. Higher yields of citric acid $(13.0 \%)$ observed with $\mathrm{Cu}^{2+}$ added fermentation media prepared with orange peels (Table-3). ${ }^{36}$ Reported that copper and zinc favored citric acid production while iron and manganese displayed harmful impact on the bioaccumulation of citric acid.

\section{CONCLUSION}

Based on the results of the present study, it could be concluded that the fruit waste i.e. orange peel is a potential substrate to produce citric acid. The study explored the efficient way to minimize environmental pollution due to dumping of fruit wastes. Citric acid production by utilizing the fruit waste as the substrate is very economical, especially when the fermentation conditions are optimized. Supplementation of nutrients on to the media had high degree of positive correlation to the yield of citric acid. This study also represents that the production of citric acid from fruit waste is an efficient way of recycling the waste generated from fruit processing industries.

\section{REFERENCES}

1. Max, B., Salgado,J.M., Rodriguez, N., Cortes,S., Converti, A Dominguez, J.M. Biotechnological production of citric acid. Braz. J. Microbiol., 2010. 41 (4): 862-875.

2. Soccol, C. R., Prado, F. C., Vandenberghe, L. P. S. Pandey, A. General aspects in citric acid production by submerged and solid-state fermentation. s. In: Concise Encyclopedia of Bioresource Technology, The Haworth Press. New York, 2003. 652-664.

3. Jianlong, W. Production of citric acid by immobilized Aspergillus niger using a rotating biological contactor. Bioresource Technology, 2000. 75: 245-247.

4. Pandey, A., Soccol, C.R., Rodriguez- Leon, J.A. Nigam, P. Production of organic acids by solid state fermentation. In: Solid state fermentation in biotechnology-fundamental and applications. s Asiatech Publishers. New Delhi, 2001. 113-126.

5. Kapoor, K.K., Chaudhary, K. Tauro, P. Prescott and Dunn's Industrial Microbiology, $4^{\text {th }}$ edn. G. Reed (Ed), AVI Publishing Co, Wesrport, CT. 1982.

6. Soccol, C. R. Vandenberghe, L. P. S. Overview of applied solidstate fermentation in Brazil. Biochem. Eng. Journal., 2003. 13: 205-218.

7. Khadijah-Al-Khadir. Mohd, M. K. Production of citric acid from citrus fruit wastes by local isolate and MTCC 281 Aspergillus niger strains. International Journal of Engineering Science and Technology, 2011. 3: 4849-4850.

8. Ma, E., Cervera, Q. Sánchez, G.M. Integrated utilization of orange peel. Bioresource Technology, 1993. 44:61-63.

9. Rivas, B., Torrado, A., Torre, P., Converti, A. Domínguez, J.M. Submerged citric acid fermentation on orange peel autohydrolysate. J. Agric. Food Chem., 2008. 56:2380-2387.

10. Torrado, A.M., Cortes, S., Salgado, J.M., Max, B., Rodriguez, B., Bibbins, B.P., Converti.A. Dominguez. J.M. Citric Acid production from Orange Peel Wastes by Solid-State Fermentation. Braz. J. Microbiol., 2011. 42(1):394-409. 
11. Guimaraes, R. L., Barros, J. C. M., Barrerira, M. J., Sousa, A. M., Carvlho, I. C. Ferreira, F.R. Targeting excessive free radicals with peels and juices of citrus fruits: grape fruits, lemon, lime and orange. Food Chem. Toxicol., 2010. 48:99-106.

12. Kareem, S.O., Akpan, I. Aleblowu, 0.0. Production of citric acid by Aspergillus niger using pineapple waste. M. J. Microbiol., 2010. 6(2): 161-165.

13. Dhandayuthapani, K., Thiyageswaran, G. Pradeep, K.S. Production of citric acid from banana waste by Aspergillus niger. Intl J. Appl. Bioeng. 2008. 2: 35-38.

14. Cherrington, C.A., Hinton, M., Mead, G.C. Chopra, I. Organic acids: Chemistry, antibacterial activity and practical applications. Adv. Microbiol. Physiol., 1991. 32:87-108.

15. Milson, P.E. Meers, J.L. Citric Acid in "Comprehensive Biotechnology" Murray Moo-Young Eds. Pergamon Press, Inc. 1985. 3: 665-680.

16. Moeller, L., Strehlitz, B., Aurich, A., Zehnsdorf, A. Bley, T Optimization of citric acid production from glucose by Yarrowia lipolytica. Eng. Life Sci., .2007. 7 (5):504-511.

17. Narayanamurthy, G., Ramachandra, Y.L., Padmalatha Raj, S., Sujan Ganapathy, P.S., Kavitha, B.T. Manohara, Y.N. Comparative studies on submerged, liquid surface and solid state fermentation for citric acid production by Aspergillus niger RCNM17. Asian J. Microbiol. Biotech. Environ. Sci., 2008. 10 (2):361-364.

18. Sukesh, K., Jayasuni, J.S., Gokul C.N. Anu, V. Citric acid production from agronomic waste using Aspergillus niger isolated from decayed fruit. J. Chem. Bio.Phy.Sci., 2013. 2:1572-1576.

19. Hang, Y.D. Woodams, E.E. Microbial production of citric acid by solid state fermentation of kiwifruit peel. J. Food Sci., 1987. 52: 226-227.

20. Hang, Y.D. Woodams, E.E. Utilization of grape pomace for citric acid production by solid-state fermentation. Am. J. Enol. Vitic., 1986. 37(2):141-2.

21. Tran, C.T. Mitchell, D.A. Pineapple waste - a novel substrate for citric acid production by solid state fermentation. Biotechnology Letters, 1995. 17(10): 1107-1110.

22. Shojaosadati, S.A. and Babaeipour, V. Citric acid production from apple pomace in multi- layer packed bed solid-state bioreactor. Process Biochemistry, 2002. 37(8): 909-914.

23. Moyer, A.J. Effect of methanol on the mycological production of citric acid in surface and submerged culture. Appl Microbiol., 1953. 1:1-7.
24. Yigitoglu, M. Production of citric acid by fungi. Journal of Islamic Academy of Sciences, 1992. 5(2):100-106.

25. Kubicek, C.P. Rohr, M. Citric acid fermentation, CRC Crit. Rev. Biotechnol., 1986. 3:331.

26. Steel, R., Lentz, C.P. Martin, S.M. Submerged citric acid fermentation of sugar beet molasses: Increase in scale. Can J Microbiol., 1955. 1, 299.

27. Hossain, M., Brooks, J.D. Moddax, I.S. The effect of the sugar source on citric acid production by Aspergillus niger. Applied Microbiology and Biotechnology, 1984. 19: 393-397.

28. Drysdale, C. R. McKay, M. H. Citric acid production by Aspergillus niger on surface culture on inolin. Letters of Applied Microbiology, 1995. 20:252-254.

29. Mahavir, P.A. Sahebrao, P.V. Factors affecting microbial production of citric acid. International Referred Reseach Journal, 2011. 3: 37-38.

30. Soccol, C.R., Luciana, P.S., Berghe, V., Cristine, R. Pandey, A. Citric acid production. Food Technol. Biotechnol., 2006. 44:141-149.

31. Xu, D.B., Madrid, C.P., Rohr, M. Kubicek, C.P. The influence of type and concentration of the carbon source on production of citric acid by Aspergillus niger. Applied Microbiology and Biotechnology, 1989. 30: 553-558.

32. Mckay, I.A., Maddox, I.S. Books, J.D. High specific rates of glucose utilization under conditions of restricted growth are required for citric acid accumulation by Yarrowia lipolytica IMK2. Applied Microbiology and Biotechnology, 1994. 41:73-78.

33. Boominathan, S., Dhanaraj, T.S. Murugaiah, K. Production and optimization of citric acid by Aspergillus niger using pineapple and Tapioca waste. Herbal Tech Industry, 2012. 8: 614-615.

34. Wieczorek, S. Braver, H. Continuous production of citric acid with recirculation of the fermentation broth after product recovery. Bioprocess Eng., 1998. 18:1-5.

35. Kiel, H., Guvrin, R. Henis, Y. Citric acid fermentation by Aspergillus niger on low sugar concentrations and cotton waste. Applied Environmental Microbiology, 1981. 42:1-4.

36. Kareem, S.O. Rahman, R.A. Utilization of banana peels for citric acid production by Aspergillus niger. Agric. Biol. J. N. Am., 2011. 4(4): 384-387.

37. Nadeem, A., Syed, Q., Baig, S., Irfan, M. Nadeem, M. Enhanced production of citric acid by Aspergillus niger M-101 using lower alcohols. Turk J Biochem., 2010. 35 (1):7-13. 